\title{
EFEKTIVITAS SHORTWAVE DIATHERMY DAN NEURODYNAMIC MOBILIZATION PADA RADIKULOPATI LUMBOSAKRAL
}

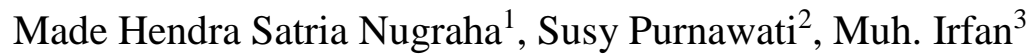 \\ ${ }^{1}$ Departemen Fisioterapi, Fakultas Kedokteran, Universitas Udayana \\ ${ }^{2}$ Departemen Faal, Fakultas Kedokteran, Universitas Udayana \\ ${ }^{3}$ Program Studi Sarjana dan Profesi Fisioterapi, Universitas 'Aisyiyah \\ Email: hendra_satria@unud.ac.id
}

\begin{abstract}
ABSTRAK
Radikulopati adalah suatu kelainan sistem saraf perifer yang terjadi pada radiks spinalis yang mengakitbatkan terjadinya gangguan sensorik, defisit motorik dan atau refleks, serta terjadinya nyeri. Pada pasien radikulopati lumbosakral terjadi suatu kondisi yang disebut sebagai fear avoidance belief yaitu ketakutan untuk bergerak atau merasakan nyeri sebagai akibat dari melakukan suatu aktivitas. Ketakutan dalam bergerak ini menyebabkan seseorang membatasi pergerakannya, sehingga otot yang seharusnya menstabilisasi kolumna vertebra tidak aktif dan otot global menjadi hiperaktif dan memicu terjadinya spasme otot.Pendekatan terapi konservatif yang dapat diberikan pada pasien radikulopati lumbosakral, meliputi pengaplikasian modalitas dan terapi oleh fisioterapi, yaitu melalui pemberian modalitas electrophysical agents, exercise therapy/terapi latihan, serta intervensi manual therapy. Tujuan literature review ini adalah untuk mengetahui efektivitas pemberian intervensi shortwave diathermy dan neurodynamic mobilization pada penderita radikulopati lumbosakral. Metode pada penelitian ini adalah literature review atau studi literatur artikel menggunakan data sekunder berupa kajian jurnal penelitian yang berkaitan dengan efektivitas intervensi shortwave diathermy dan neurodynamic mobilization pada radikulopati lumbosakral. Penelitian terdahulu membuktikan bahwa penambahan SWD pada pelatihan yang diberikan pada subjek dengan keluhan chronic back pain mampu menurunkan nyeri. Sedangkan neurodynamic mobilization adalah teknik terapi yang menerapkan konsep fisiologis dan mekanis dari sistem saraf yang berintegrasi dengan sistem muskuloskeletal. Penjelasan yang tepat terhadap perbaikan tingkat nyeri dan disabilitas fungsional yang dialami oleh pasien dengan teknik intervensi mobilisasi saraf adalah bahwa teknik neurodynamic yang dapat mempengaruhi fungsi mekanik pada saraf perifer, dan perubahan fungsi mekanis saraf ini berdampak langsung pada perubahan fisiologis struktur saraf. Berdasarkan kajian pustaka tersebut, maka dapat disimpulkan bahwa: kombinasi shortwave diathermy dan neurodynamic mobilization efektif dalam memperbaiki keterbatasan gerak dan fungsi penderita radikulopati lumbosakral.
\end{abstract}

Kata kunci: shortwave diathermy, neurodynamic mobilization, radikulopati lumbosakral

\section{THE EFFECTIVENESS OF SHORTWAVE DIATHERMY AND NEURODYNAMIC MOBILIZATION ON LUMBOSACRAL RADICULOPATHY}

\begin{abstract}
Radicular syndrome is one type of disease that is included in peripheral nervous system disorders that occur in the spinal roots causing a disturbance of sensory deficits, motor deficits, reflex deficits and damage to pain sensation. In lumbosacral radiculopathy patients, a condition
\end{abstract}


known as fear avoidance belief is a fear to move or to feel pain as a result of doing an activity. This fear of moving causes patients to restrict its movement, so the muscles that should stabilize the inactive vertebral column and the global muscle become hyperactive and trigger muscle spasms. Conservative therapy approaches that may be given to lumbosacral radiculopathy include application of modalities and therapy by physiotherapy, giving modalities of electro physical agents, exercise therapy, and manual therapy interventions. The purpose of this literature review was to determine the effectiveness of intervention shortwave diathermy and neurodynamic mobilization in patients with lumbosacral radiculopathy. The research method used is the study of literature review by using secondary data in the form of study research journals related to the effectiveness of the use of shortwave diathermy and neurodynamic mobilization in patients with lumbosacral radiculopathy. Previous research has shown that the addition of SWD to treat the subjects with chronic back pain complaints can reduce pain. While neurodynamic mobilization is a clinical application to the physiological and mechanical concepts of the nervous system that integrate with the musculoskeletal system. The precise explanation for the improvement of functional disability and pain level experienced by patients with neurodynamic is that neurodynamic may affect the mechanical functioning of peripheral nerves and the change in neural mechanical function have a direct impact on the physiological changes of nerve structure. Based on the literature review, it can be concluded that: the combination of shortwave diathermy and neurodynamic mobilization is effective in improving the limitations of motion and function of lumbosacral radiculopathy patients.

\section{Keywords: shortwave diathermy, neurodynamic mobilization, lumbosacral radikulopathy}

\section{PENDAHULUAN}

Radikulopati adalah suatu kelainan sistem saraf perifer yang terjadi pada radiks spinalis yang mengakitbatkan terjadinya gangguan sensorik, defisit motorik dan atau refleks, serta kerusakan sensasi nyeri. ${ }^{1}$ Radikulopati disebabkan oleh adanya gangguan struktural pada medulla spinalis dan vertebra yang dapat memberikan gangguan pada radiks spinalis. ${ }^{2}$ Insiden radikulopati mencapai 83 per 100.000 penduduk setiap tahunnya. Individu yang berusia antara 13 sampai 91 tahun, sebanyak 21,9\% mempunyai gambaran protrusi pada diskus. ${ }^{3}$ Segmen servikal dan lumbal merupakan segmen terbanyak terjadinya radikulopati. Sebanyak $3-5 \%$ populasi di dunia mengalami radikulopati pada bagian lumbal. Perempuan dan laki-laki memiliki kecenderungan yang sama untuk menderita radikulopati lumbal. ${ }^{3}$

Berdasarkan penyebabnya, radikulopati pada segmen lumbosakral dibagi menjadi tiga jenis, yaitu: (1). Radikulopati akibat proses degeneratif yaitu kelainan yang bersifat degeneratif seperti gangguan struktural akibat degenerasi struktur di sekitar radiks saraf. ${ }^{1}$ (2). Radikulopati akibat proses kompresif.
Kelainan yang bersifat kompresif dapat mengakibatkan sindrom radikular seperti: hernia nucleus pulposus (HNP), neoplasma tulang, cervical spondilosis, kompresif fraktur, scoliosis, tumor medulla spinalis, spondilolisthesis, stenosis spinal, traumatic dislokasi, dan spondilitis tuberkulosa. ${ }^{4}$ (3). Radikulopati akibat proses inflammasi. Kelainan-kelainan tersebut seperti: Herpes Zoster dan Gullain-Barre Syndrome. ${ }^{5}$ Gejala klinis pada radikulopati berkisar antara dua minggu sampai dengan empat tahun. Pada $70 \%$ kasus saat kunjungan pertama tercatat lebih dari intensitas nyeri yang dirasakan pasien yang diukur dengan numeric pain scale adalah lebih dari tujuh.,

Pada pasien radikulopati lumbosakral terjadi suatu kondisi yang disebut sebagai fear avoidance belief yaitu ketakutan untuk bergerak atau merasakan nyeri sebagai akibat dari melakukan suatu aktivitas. Ketakutan dalam bergerak ini menyebabkan seseorang membatasi pergerakannya, sehingga otot yang seharusnya menstabilisasi kolumna vertebra tidak aktif dan otot global menjadi hiperaktif dan memicu terjadinya spasme otot. $^{6}$ Pendekatan terapi konservatif yang dapat 
diberikan pada pasien radikulopati lumbosakral, meliputi pengaplikasian modalitas dan terapi oleh fisioterapi, yaitu melalui pemberian modalitas electrophysical agents, exercise therapy/terapi latihan, serta intervensi manual therapy. Jika pendekatan penanganan radikulopati lumbosakral hanya terbatas pada aplikasi berupa terapi latihan ataupun manual terapi maka penanganan yang diberikan menjadi kurang efektif. Terlebih lagi, penanganan di klinik fisioterapi masih menggunakan superficial heating seperti infrared sebagai modalitas elektroterapi. Oleh karena itu, dibutuhkan modalitas elektroterapi yang mampu menghasilkan efek thermal dengan penetrasi yang cukup dalam seperti aplikasi shortwave diathermy (SWD). Pendekatan manual terapi juga dapat diaplikasikan melalui pemberian neurodynamic mobilization.

\section{METODE}

Metode pada penelitian ini adalah literature review atau studi literatur artikel menggunakan data sekunder berupa kajian jurnal penelitian yang berkaitan dengan efektivitas intervensi shortwave diathermy dan neurodynamic mobilization pada radikulopati lumbosakral.

\section{PEMBAHASAN}

Kombinasi Shortwave Diathermy dan Neurodynamic Mobilization dalam Tatalaksana Penanganan Radikulopati Lumbosakral

Diathermy merupakan aplikasi dari penggunaan gelombang elektromagnetik berfrekuensi tinggi yang bertujuan untuk menghasilkan panas bagi jaringan tubuh. Diathermy juga dapat digunakan untuk memproduksi efek non-thermal. Diathermy sebagai suatu agen terapeutik dapat diklasifikasikan menjadi 2 modalitas, yaitu: shortwave dan microwave diathermy. Shortwave diathermy (SWD) dapat diklasifikasikan lagi menjadi continous dan pulsed shortwave diathermy. Kedalaman penetrasi dari shortwave diathermy lebih dalam jika dibandingkan dengan modalitas infrared, sehingga dapat digunakan untuk mengatasi permasalahan muskuloskeletal. Berdasarkan aturan The Federal Communications Commission (FCC), SWD terdiri atas 3 unit berdasarkan frekuensi dan panjang gelombangnya, yaitu: (1) $27,12 \mathrm{MHz}$ dengan panjang gelombang sebesar $11 \mathrm{~m},(2)$ 13,56 $\mathrm{MHz}$ dengan panjang gelombang sebesar $22 \mathrm{~m}$, dan yang paling jarang digunakan (3) 40,68 $\mathrm{MHz}$ dengan panjang gelombang sebesar 7,5 m. Suatu unit SWD yang menghasilkan arus listrik berfrekuensi tinggi akan menghasilkan electrical field dan magnetical field dalam jaringan. SWD dengan frekuensi 13,56 $\mathrm{MHz}$ akan memproduksi magnetic field yang lebih besar jika dibandingkan dengan frekuensi 27,12 $\mathrm{MHz}$ yang memproduksi electrical field yang besar. Pada pulsed SWD lebih banyak menggunaan drum electrode dan memproduksi magnetic field yang lebih besar. ${ }^{7}$

SWD tidak mampu menghasilkan kontraksi otot skeletal dikarenakan panjang gelombangnya terlalu pendek dalam satu durasi. Oleh karena itu, efek fisiologis yang diharapkan dari penggunaan SWD yaitu efek thermal (panas) yang dihasilkan oleh getaran molekul berfrekuensi tinggi. Efek primer dari penggunaan SWD di antaranya adalah pemanfaatan panas secara umum meliputi: peningkatan suhu jaringan, meningkatkan aliran darah, dilatasi pembuluh darah, peningkatan filtrasi dan difusi antar membran, meningkatkan laju metabolik jaringan, mengurangi kekakuan sendi, relaksasi otot, dan meningkatkan perbaikan jaringan setelah cedera. ${ }^{7}$ Lehmann dalam (Prentice et.al., 2002) menyebutkan bahwa peningkatan suhu pada jaringan sebesar $1^{\circ} \mathrm{C}$ dapat mengurangi inflamasi dan meningkatkan metabolism, peningkatan suhu $2-3^{\circ} \mathrm{C}$ akan mengurangi nyeri dan spasme otot, sedangkan peningkatan suhu lebih dari $3-4^{\circ} \mathrm{C}$ akan meningkatkan ekstensibilitas jaringan sehingga memungkinkan praktisi untuk mengobati permasalahan kronis pada jaringan. Peneliti lainnya meyakini bahwa 
pemanasan optimal pada suhu jaringan sebaiknya dicapai pada suhu di atas $38-40^{\circ} \mathrm{C}$ atau peningkatan $3-4^{\circ} \mathrm{C}$ di atas baseline. Pulsed SWD digunakan untuk menghasilkan efek nonthermal pada cedera soft-tissue atau perbaikan jaringan. Mekanisme perbaikannya dijelaskan pada tingkat sel yang berhubungan pada potensi membrane sel yang spesifik. Pulsed SWD membantu repolarisasi sel yang rusak sehingga memperbaiki fungsi dari sel. Ketika magnetic field diinduksikan, maka pompa sodium akan tereaktivasi sehingga memungkinkan sel untuk mendapatkan kembali keseimbangan ionnya. ${ }^{7}$

Diketahui pula bahwa diathermy dapat meningkatkan fleksibilitas jaringan tanpa dilakukan penguluran. Penelitian yang dilakukan oleh (Robertson et.al., 2005) mengaplikasikan pemberian SWD selama 15 menit pada kaki dengan menggunakan capacitive pads dan subjek penelitian tidak diberikan penguluran setelah pemberian modalitas elektroterapi. Hasil penelitian ini menunjukkan bahwa terdapat peningkatan lingkup gerak sendi ankle dorsiflexion sebesar 5,2\% setelah diberikan SWD dan peningkatan sebesar $2 \%$ pada aplikasi hot packs, sedangkan pada kelompok yang tidak diberikan modalitas elektroterapi, tidak terdapat peningkatan lingkup gerak sendi. ${ }^{7}$ McCray dan Patton dalam (Michlovitz et.al., 2016) membandingkan efek SWD dengan hot packs terhadap sensitivitas trigger points pada leher, bahu, dan punggung. Hasil penelitian yang didapatkan menyimpulkan bahwa aplikasi SWD lebih efektif dalam menurunkan nyeri daripada hot packs. ${ }^{8}$ Penelitian lainnya dari (Kim et.al., 2012) menyimpulkan bahwa terdapat perbaikan yang signifikan pada pasien chronic low back pain setelah pemberian SWD dengan intensitas $50 \mathrm{~W}$ yang dikombinasikan dengan pemberian neurodynamic mobilization. Penelitian dari Draper, et.al. (2013) membuktikan bahwa Pulsed Short Wave Diathermy dengan average power $48 \mathrm{~W}$ dapat meningkatkan suhu jaringan sampai kedalaman $3 \mathrm{~cm}$ dengan peningkatan mencapai $4,6^{\circ} \mathrm{C}^{7,9}$ Penelitian dari (Khan, S., et.al, 2013) membuktikan bahwa penambahan SWD pada pelatihan yang diberikan pada subjek dengan keluhan chronic back pain mampu menurunkan nyeri setelah dievaluasi dengan menggunakan Visual Analogue Scale serta McGill Pain Questionnaire. ${ }^{7}$

Hal ini dikarenakan mekanisme SWD mempengaruhi dalam empat mekanisme yaitu: (1) reaksi metabolik, (2) efek vaskular, (3) efek neuromuskular, dan (4) efek pada connective tissue. (1) Reaksi Metabolik. Reaksi kimia pada sel tubuh dipengaruhi oleh suhu. Aktivitas kimia dan laju metabolik pada sel akan meningkat $2-3$ kali setiap peningkatan suhu $10^{\circ} \mathrm{C}$. Oleh karena itu, pengeluaran energi akan meningkat seiring dengan peningkatan suhu. Dengan peningkatan suhu yang optimal, maka oksigen akan lebih banyak tersedia di jaringan. Dengan demikian, akan banyak nutrisi yang tersedia sebagai bahan dalam reparasi jaringan. Apabila panas yang dihasilkan melebihi titik tertentu, biasanya suhu mencapai $45^{\circ} \mathrm{C}-50^{\circ} \mathrm{C}$, maka jaringan akan rusak karena terjadi denaturasi protein.(2) Efek Vaskular. Peningkatan suhu jaringan biasanya berkaitan dengan vasodilatasi yang berhubungan dengan peningkatan aliran darah ke suatu area. Aliran darah pada kulit sangatlah penting dalam menjaga nutrisi dan suhu tubuh yang tetap dan sistem ini ada di bawah kontrol dari sympathetic adrenergic nerves. Vasodilatasi pada kulit akan terjadi akibat pengeluaran panas melalui mekanisme lokal atau refleks. Kulit sangat unik karena memiliki pembuluh darah yang spesial yang disebut arteriovenous (AV) anastomoses, yang memiliki peran penting dalam pengeluaran panas. Aktivasi refleks terjadi ketika mendapatkan stimulasi suhu terkait pelepasan panas melalui regio preoptik di hipotalamus anterior. $A V$ shunt ini terdapat di tangan, kaki, serta wajah. Peningkatan aliran darah pada kulit dapat terjadi karena mekanisme lokal atau refleks yang disebabkan oleh: (1) refleks akson, (2) pelepasan mediator kimia akibat peningkatan 
suhu, (3) refleks lokal spinal cord. SWD yang diaplikasikan pada tubuh pasien, akan mengaktivasi termoreseptor pada kulit. Sistem sensory afferents ini akan menghantarkan informasi ke spinal cord dan sebagian lainnya akan diteruskan ke percabangan pembuluh darah di kulit, serta pelepasan mediator vasoaktif.Panas juga akan memproduksi reaksi inflamasi yang ringan. Mediator kimia inflamasi seperti histamin dan prostaglandin akan dilepaskan dan menyebabkan pembuluh darah bervasodilatasi. Mekanisme lain yang terjadi bahwa peningkatan suhu menyebabkan sekresi kelenjar keringat. Enzim akan bekerja pada globulin dan kininogen untuk melepaskan bradikinin. Vasodilatasi pada pembuluh darah (small arteries dan arterioles) dan peningkatan pemeabilitas venule kapiler dan post-kapiler terjadi karena kerja dari mediator kimia pada otot polos dan kontraktilitas sel endotelial. Karena terjadi peningkatan permeabilitas dan tekanan hidrostatik kapiler, filtrasi cairan dari vaskular ke area ekstravaskular menjadi baik. Oleh karena itu, panas yang dihasilkan melalui therapeutic heat seperti SWD, akan menyebabkan peningkatan yang potensial terhadap cairan intersitial dan menyebabkan inflamasi ringan. Refleks lokal pada spinal cord akan dilepaskan selama aktivasi dari serabut aferen di kulit. Refleks ini terjadi akibat penurunan aktivitas saraf adrenergik pada postganglionic sympathetic ke pembuluh darah pada otot polos. (3) Efek Neuromuskular. Therapeutic heat digunakan untuk menghasilkan efek analgesik dan membantu dalam meresolusi nyeri serta muscle-guarding spasms. (4) Efek pada Connective Tissue.Peningkatan suhu yang dikombinasikan dengan penguluran dapat mempengaruhi komponen viskoelastik dari connective tissue yang disebut sebagai mekanisme plastic deformation atau elongation. Struktur yang elastik akan teregang di bawah suatu pembebanan, akan tetapi mampu kembali lagi ke panjangnya semula ketika pembebanan tersebut dihilangkan. Sebuah penelitian yang membandingkan antara penggunaan PSWD dengan Ultrasound $1 \mathrm{MHz}$ membuktikan bahwa, efek panas setelah aplikasi alat lebih lama bertahan pada aplikasi PSWD sekitar $60 \%$ lebih lama daripada aplikasi dengan menggunakan ultrasound $1 \mathrm{MHz}$. Hal ini sangatlah penting untuk memaksimalkan efek yang ingin dihasilkan melalui stretching, friction massage, atau mobilisasi sendi sebelum suhu pada tubuh benar-benar turun ke level yang kurang efektif. 7,10

Neurodynamic mobilization adalah teknik terapi yang menerapkan konsep fisiologis dan mekanis dari sistem saraf yang berintegrasi dengan sistem muskuloskeletal. Dalam neurodynamic, terdapat tiga bagian sistem yang menjadi fondasi dalam aplikasinya yaitu: Hambatan Mekanis (Mechanical Interface), Struktur Saraf (Neural Structure), dan Jaringan yang dipersarafi (Innervated Tissue). ${ }^{11}$ Mechanical Interface merupakan segala struktur yang berada disekitar sistem saraf. Dalam konteks ini, yang termasuk Mechanical Interface adalah tendon, otot, tulang, diskus intervertebralis, ligamen, fascia, dan pembuluh darah. Mechanical interface bergerak seiring dengan pergerakan sistem saraf selama aktifitas fungsional. Struktur saraf di dalamnya termasuk otak, saraf kranial dan medulla spinalis, akar saraf, dan saraf perifer. Fungsi dari struktur saraf dalam konsep neurodynamic dapat dibagi menjadi dua yaitu fungsi fisiologis mencakup intraneural bloodflow, konduksi impuls, transport aksonal, inflamasi, sensitivitas mekanis; serta fungsi mekanis yang mencakup tension, sliding, compression. Sedangkan innervated tissue merupakan segala jaringan yang mendapatkan inervasi dari sistem saraf dan merupakan penyebab dasar terjadinya gannguan pada sistem saraf.

Sistem saraf memiliki kemampuan alami untuk bergerak terhadap mechanical interface nya. Kapasitas ini memungkinkan sistem saraf untuk terhindar dari injuri dan malfungsi. Untuk dapat bergerak secara normal, sistem saraf harus berhasil dalam 
melakukan 3 fungsi mekanis primer. Tiga fungsi mekanis tersebut di dalamnya meliputi: 1) fungsi untuk menerima beban ketegangan (tension), 2) fungsi mekanis saraf untuk bergeser (sliding) terhadap hambatan mekanisnya, serta 3) fungsi mekanis saraf untuk menerima beban kompresi terhadap hambatan mekanisnya. Tension adalah suatu keadaan dimana struktur saraf mengalami pemanjangan oleh pergerakan dari jaringan yang diinervasi pada kedua ujung perlekatan. Sliding merupakan kemampuan mekanis saraf untuk bergeser/bergerak terhadap jaringan serta mechanical interface disekitarnya. Fungsi sliding dapat terjadi baik secara longitudinal maupun secara transversal dan pada umumnya berperan dalam mengurangi ketegangan (tension) pada struktur saraf. Compression merupakan fungsi struktur saraf untuk menerima beban penekanan yang pada umumnya dihasilkan oleh mechanical interface.

$\begin{array}{ccc}\text { Dalam } & \text { kaitannya } & \text { terhadap } \\ \text { neurodynamics, } & \text { mechanical } & \text { interface }\end{array}$ memiliki peran penting dalam keberhasilan struktur saraf dalam menghasilkan pergerakan normal. Terdapat dua jenis pergerakan yang dapat terjadi pada mechanical interface yaitu gerakan membuka (Opening mechanism) dan gerakan menutup (Closing Mechanism). Baik gerakan membuka maupun menutup memiliki dampak yang penting dalam regulasi aliran darah intraneural serta implikasinya terhadap penekanan yang terjadi pada struktur saraf. Mekanisme menutup adalah pergerakan yang dihasilkan oleh hambatan mekanis yang menyebabkan meningkatnya tekanan intraneural pada struktur saraf oleh karena berkurangnya ruang disekitar struktur saraf. Beberapa maneuver seperti phalen test, gerakan ekstensi dan lateral fleksi ipsilateral dari tulang belakang dapat mengurangi ruang disekitar struktur saraf. Mekanisme membuka adalah pergerakan yang dihasilkan oleh hambatan mekanis yang dimana dapat mengurangi penekanan pada struktur saraf oleh karena meningkatnya ruang gerak disekitar struktur saraf yang dihasilkan oleh maneuver tertentu. Beberapa contoh maneuver yang dapat menghasilkan mekanisme membuka adalah ekstensi siku pada kasus Ulnar Neuritis, elevasi scapula pada kasus Thoracic Outlet Syndrome, serta gerakan fleksi dan lateral fleksi kontralateral pada tulang belakang dapat meningkatkan ruang pada foramen intervertebralis. ${ }^{11}$

Dalam Neurodynamics, terdapat dua teknik yang dapat diaplikasikan berdasarkan disfungsi pada struktur saraf yang terjadi yaitu teknik Sliders dan teknik Tensioners. (1) Teknik Slider. Teknik Slider merupakan teknik neurodynamic dimana menggunakan pergerakan tubuh untuk menggerakkan struktur saraf pada kedua ujung dalam arah yang sama. Pada teknik sliders, tidak terjadi ketegangan oleh karena kedua ujung bergerak dalam arah yang sama. Teknik sliders sangat baik diberikan pada permasalahan neurologis yang dimana nyeri menjadi fokus utama dalam pengobatan. Teknik sliders utamanya diberikan pada kasus neural sliding dysfunction, yaitu suatu kondisi dimana terjadi gangguan mekanis pada pergeseran struktur saraf terhadap hambatan mekanisnya. Teknik sliders juga dapat diberikan pada fase awal tension dysfunction.(2) Teknik Tensioner. Teknik Tensioner merupakan teknik neurodynamic dimana mobilisasi saraf yang dilakukan adalah dengan menggerakan struktur saraf pada kedua ujung dalam arah yang berlawanan. Pada teknik tensioner, fokus utama pengobatan adalah berkurangnya fleksibilitas saraf atau berkurangnya kemampuan saraf untuk menerima beban tension (neural tension dysfunction). Teknik tensioner pada umumnya dilakukan pada disfungsi saraf yang bersifat kronis.

Neurodynamic Mobilization merupakan suatu teknik manual terapi yang ditujukan untuk meningkatkan mobilitas sistem saraf terhadap jaringan di sekitarnya melalui pergerakan trunk, ekstremitas atas dan bawah yang sistematis. Teknik ini bertujuan untuk meningkatkan mikrosirkulasi intraneural dan meningkatkan fungsi mekanis struktur saraf dalam hal tension, sliding, dan compression. 
Penerapan mobilisasi saraf dengan memposisikan pasien dalam dua posisi yaitu Straight Leg Raising dan Slump Stretching. Intervensi dilakukan sebanyak 6x dengan teknik yang berbeda-beda. Pada intervensi 1 \& 2, fokus intervensi ditujukan pada mechanical interface dengan melakukan opening technique dan kemudian closing technique. Pada intervensi 3 hingga 6, difokuskan pada struktur saraf dengan melakukan gerakan mobilisasi saraf dalam 4 tahapan yaitu position away - move away, position toward - move away, position away - move toward, dan terakhir position towardmove toward. Dalam setiap intervensi, dilakukan dalam beberapa repetisi hingga sensitivitas berkurang (ditahan selama 30 detik dan 5 kali repetisi), diawali dengan gerakan pasif oleh terapis dan diakhiri dengan gerakan aktif (self mobilization) oleh pasien.

Penjelasan yang tepat terhadap perbaikan tingkat nyeri dan disabilitas fungsional yang dialami oleh pasien dengan teknik intervensi mobilisasi saraf adalah bahwa teknik neurodynamic yang dapat mempengaruhi fungsi mekanik pada saraf perifer, dan perubahan fungsi mekanis saraf ini berdampak langsung pada perubahan fisiologis struktur saraf. ${ }^{12,13}$ Penelitian berhasil menunjukkan bahwa mobilisasi saraf menghasilkan pemanjangan longitudinal dan regangan dalam jumlah tinggi. ${ }^{14,15,16}$ Teknik mobilisasi saraf membantu memulihkan pergerakan antara saraf dan struktur sekitarnya melalui gerakan sliding. Oleh karena itu, tekanan intrinsik pada jaringan saraf menurun yang kemudian meningkatkan fungsi saraf. ${ }^{12,17}$ Kompresi akar saraf karena herniasi disk menghambat aliran darah di dalam akar saraf, perubahan mikrosirkulasi saraf ini menyebabkan rasa nyeri dan pelepasan mediator inflamasi. ${ }^{18,19}$ Selebihnya, terjadi blok pada sistem konduksi saraf, edema, dan sensitisasi mekanik juga dihasilkan dari kompresi akar saraf. ${ }^{18,20,21}$ Teknik mobilisasi saraf meningkatkan aliran darah intraneural, aliran axoplasmic, aktivasi simpatis yang selanjutnya, membantu dalam penyerapan cairan pada jaringan dan mengurangi edema intraneural. ${ }^{11,17,22,23}$ Temuan ini sependapat dengan penelitian yang dilakukan Cleland, dkk.(2006) yang melaporkan bahwa kompresi akar saraf dapat menghambat mikrosirkulasi akar saraf sehingga menyebabkan edema saraf dan penerapan teknik mobilisasi saraf berhasil mengurangi dan menghilangkan edema. Selain itu, Santos, et al., (2012), melaporkan bahwa mobilisasi saraf dapat digunakan secara efektif untuk mengurangi mediator inflamasi dan nyeri setelah menyelidiki pengaruhnya terhadap cedera saraf sciatica pada tikus. ${ }^{24}$ Selanjutnya, Bertolini, et al., (2009), melaporkan bahwa edema intranural dan adhesi menurun dan akibatnya memulihkan sensitivitas mekanik saraf setelah peregangan saraf sciatic setelah eksperimen yang dilakukan pada tikus. ${ }^{25}$ Gladson dkk (2009) menyatakan bahwa ketika akar saraf mengalami penekanan dan mikrosirkulasi terganggu, dan tekanan yang diterima oleh jaringan saraf akan menghasilkan edema dan dimyelinisasi, maka teknik mobilisasi saraf yang menggunakan gerakan osilasi yang pendek cukup untuk menurunkan edema, sehingga mengurangi hipoksia jaringan dan mengurangi gejala terkait. ${ }^{26}$

Dalam penelitian lain yang dilakukan oleh Brown, dkk (2011) pada kadaver, teknik mobilisasi saraf dapat mengurangi atau mencegah edema intraneural pada saraf tibialis akibat peningkatan dispersi cairan. ${ }^{27}$ Selanjutnya, Beneciuk, dkk (2009) melaporkan bahwa mobilisasi saraf memiliki efek hipoalgesik pada serabut saraf $\mathrm{C}$ yang mengirimkan sinyal nyeri setelah penerapan teknik mobilisasi saraf pada saraf medianus. Efek hypoalgesic ini disebabkan oleh penghambatan sinyal nyeri pada conus dorsalis. $^{28}$ Hasil penelitian ini konsisten dengan temuan Murphy, dkk (2009) yang menyelidiki pengaruh pendekatan intervensi yang terdiri dari mobilisasi saraf, teknik myofascial dan teknik manipulasi pada pasien lumbosacral radiculopathy. Teknik 
neurodynamic mobilization diterapkan untuk meminimalkan adhesi pada akar saraf yang yang mengalami penjebakan. Sekitar $90 \%$ partisipan menunjukkan hasil yang baik, $74 \%$ melaporkan penurunan tingkat nyeri, dan $70 \%$ mengalami perbaikan pada level disabilitas fungsional. ${ }^{29}$

Selain itu, Nagrale et al (2012) meneliti pengaruh mobilisasi saraf dalam dengan teknik slump stretching pada pasien dengan LBP non-radikular.Temuan penelitian mereka berhasil menunjukkan bahwa teknik slump stretching menghasilkan perbaikan pada tingkat disabiltas fungsional, nyeri, dan ketakutan terhadap pergerakan pada pasien dengan LBP non-radikuler. ${ }^{30}$ Selain itu, Cleland dkk (2006) melaporkan bahwa mobilisasi saraf memiliki efek positif dalam memperbaiki rasa sakit, disabilitas fungsional, dan menghasilkan sentralisasi gejala. Sarkari dan Multani juga melaporkan efek menguntungkan mobilisasi saraf pada pasien dengan nyeri punggung bawah yang menjalar. Adel (2011) berpendapat bahwa gerakan struktur saraf dalam rentang bebas nyeri dapat membantu dalam mengurangi kompresi, tekanan, dan ketegangan pada struktur saraf yang berdampak baik pada menurunnya sensitivitas mekanis, sehingga memperbaiki disabilitas fungsional pada penderita. Disabilitas fungsional pada penderita HNP dengan radikulopati terjadi oleh karena intoleransi struktur saraf dalam menerima beban tegangan (tension) yang berlebihan oleh suatu gerakan sehingga menghasilkan keterbatasan gerak dan disertai nyeri. McCracking dalam penelitiannya menjelaskan bahwa teknik neurodynamic sangat berguna dalam intervensi pada kasus neural tension dysfunction.Menggunakan teknik tensioner, diharapkan mampu meningkatkan ekskursi struktur saraf dalam hal pemanjangan dan toleransi saraf dalam menerima beban tension, sehingga mampu meningkatkan aktivitas gerak fungsional baik pada ekstremitas bawah maupun pada lumbar. ${ }^{31}$

\section{SIMPULAN:}

Berdasarkan kajian pustaka tersebut, maka dapat disimpulkan bahwa: Kombinasi shortwave diathermy dan neurodynamic mobilization efektif dalam memperbaiki keterbatasan gerak dan fungsi penderita radikulopati lumbosakral.

\section{DAFTAR PUSTAKA:}

1. Baehr M., Frotscher M. 2010. Diagnosis Topik Neurologi DUUS : anatomi, fisiologi, tanda, gejala Ed. 4. Jakarta: EGC.

2. Mardjono M., Sidharta P. 2012. Neurologi Klinis Dasar. Jakarta: Dian Rakyat

3. Malanga A. Lumbosacral Radiculopathy (Online; diakses pada tanggal 7 November 2016). http://emedicine.medscape.com/

4. Neal SL, Fields KB. Peripheral nerve entrapment and injury in the upper extremity. Am Fam Physician 2010; 81(2): 147-155

5. McDonnell M, Lucas P. Cervical spondylosis, stenosis, and rheumatoid arthritis. Medicine and Health/Rhode Island 2012; 95(4). 105-109

6. Nasikhatussoraya, N. 2016. Hubungan Intensitas Nyeri dan Disabilitas Aktivitas Sehari-hari dengan Kualitas Hidup. Semarang : Fakultas Kedokteran Universitas Diponegoro

7. Prentice W, Quillen WS, Underwood F. 2002. Therapeutic Modalities forPhysical Therapy Second Edition. United States of America. The McGraw-Hill Company : 272-303

8. Michlovits, SL., Bellew, JW., dan Nolan, TP. 2012. Modalities for Therapeutic Intervention: Fifth Edition. Philadelphia: FA Davis Company

9. Draper, DO., Hawkes, AR., Johnson, AW., Diede, MT., dan Rigby, JH. 2013.Muscle Heating with Megapulse 
II Shortwave Diathermy and ReboundDiathermy. J Ath Train 48(\$): p 477 - 482

10. Prentice W, Quillen WS, Underwood F. 2002. Therapeutic Modalities forPhysical Therapy Second Edition. United States of America. TheMcGraw-Hill Company: 272-303

11. Shacklock MO. 2005. Clinical Neurodynamics: a New System of Musculoskeletal Treatment. Edinburg, UK. Elsevier Health Sciences

12. Ellis RF, Hing WA. Neural mobilization: a systematic review of randomized controlled trials with an analysis of therapeutic efficacy. J Man ManipTher. 2008;16(1):8-22

13. Kumar V , GoyalM, Rajendran N, Narkeesh D. Effect of neural mobilization on monosynaptic reflex a pretest posttest experimental design. International Journal of Physiotherapy and Research. 2013; (3):58- 62

14. Coppieters MW, Hough AD, Dilley A. Different Nerve-Gliding Exercises Induce Different Magnitudes of Median Nerve Longitudinal Excursion: An In Vivo Study Using Dynamic Ultrasound Imaging. J Orthop Sports PhysTher. 2009; 39(3):164-71

15. Coppieters MW, Butler DS. Do 'sliders' slide and 'tensioners' tension? An analysis of neurodynamic techniques and considerations regarding their application. Man Ther. 2008;13:213-221

16. Coppieters WM, Alshami AM, Barbi AS. Strain and excursion of the sciatic, tibial, and plantar nerves during a modified straight leg raising test. J. Orthop. Res. 2006; 24: 1883-1889

17. Butler DS. The Sensitive Nervous System. Noigroup Publications, Adelaide Australia. 2000

18. Kobayashi S, Yoshizawa H, Yamada S. Pathology of lumbar nerve root compression part 2: morphological and immune histo chemical changes of dorsal root ganglion. J. Orthop. Res. 2004; 22(1):180-188

19. Kobayashi S, Shizu N, Suzuki Y, Asai $\mathrm{T}$, Yoshizawa $\mathrm{H}$. Changes in nerve root motion and intraradicular blood flow during an intraoperative straightleg-raising test. Spine.2003; 28(13): 1427-1434

20. Chen C, Cavanaugh JM, Song Z, Takebayashi T, Kallakuri S, Wooley PH. Effects of nucleus pulposus on nerve root neural activity, mechanosensitivity, axonal morphology, and sodium channel expression. Spine. 2003; 29(1): 17-25

21. Rempel MD, Dahlin L, Lundborg G. Pathophysiology of nerve compression syndromes: response of peripheral nerves to loading. J. Bone Jt. Surg. 1999; 81(11):1600-1610

22. Coppieters WM, Alshami AM, Barbi AS. Strain and excursion of the sciatic, tibial, and plantar nerves during a modified straight leg raising test. J. Orthop. Res. 2006; 24: 1883-1889

23. Schmid AB, Elliott JM, Strudwick MW, Little M, Coppieters MW. Effect of splinting and exercise on intraneural edema of the median nerve in carpal tunnel syndrome-an MRI study to reveal therapeutic mechanisms. J Orthop Res. 2012; 30(8):1343-50

24. Santos FM1, Silva JT, Giardini AC, Rocha PA, Achermann AP, Alves AS, Britto LR, Chacur M.. Neural mobilization reverses behavioral and cellular changes that characterize neuropathic pain in rats. Mol. Pain.2012; 8: 1-9

25. Bertolini GR, Silva ST, Trindade LD, Ciena AP,Carvalho AR. Neural mobilization and static stretching in an experimental sciatic modelean experimental study. Braz. J. Phys. Ther. 2009;13:493-498

26. Gladson R. B, Taciane S. S, Danilo L. T, Adriano P. C, Alberito R. C 2009: 
Neural mobilization and static stretching in an experimental sciatica model - an experimental study. Revista Brasileira de Fisioterapia; 13 (6)

27. Brown CL, Gilbert KK, Brismee JM, Sizer PS, James CR, Smith MP. The effects of neurodynamic mobilization on fluid dispersion within the tibial nerve at the ankle: an unembalmed cadaveric study. J Man ManipTher. 2011; 19(1):26- 34

28. Beneciuk MJ, Bishop DM, George ZS. Effects of upper extremity neural mobilization on thermal pain sensitivity: a sham-controlled study in asymptomatic participants. J. Orthop. Sports Phys. Ther.2009; 39(6): 428438
29. Murphy RD, Hurwitz LE, McGovern EE. A non-surgical approach to the management of patients with lumbar radiculopathy secondary to herniated disk: a prospective observational cohort study with follow-up. J. Manip. Physiol.Ther. 2009; 32: 723-733

30. Nagrale AV, Patil SP, Gandhi RA, Learman K. Effectof slump stretching versus lumbar mobilization with exercise in subjects with nonradicular low back pain: a randomized clinical trial. J. Man. Manip. Ther. 2012; 20(1): 35-42

31. Adel, 2011. Efficacy of Neural Mobilization in Treatment of Low Back Dysfunction. Journal of American Science, 2011;7(4) 